\title{
Early Mass Selection Response of Two Quinoa Landraces under Highlands Conditions in Northern Chile
}

\author{
Francisco FUENTES $^{1 *}$, Atul BHARGAVA ${ }^{2}$, Claudia ROJAS-BERTINI ${ }^{1}$ \\ ${ }^{1}$ Facultad de Agronomía e Ingeniería Forestal, Facultad de Ingeniería, Facultad de Medicina, Pontificia \\ Universidad Católica de Chile, Casilla 306-22, Santiago, Chile. \\ ${ }^{2}$ Department of Botany, School of Life Sciences, Mahatma Gandhi Central University, Motihari, \\ Bihar-845401, India. \\ *corresponding author: frfuentesc@uc.cl
}

BulletinUASVM Horticulture 77(2) / 2020

Print ISSN 1843-5254, Electronic ISSN 1843-5394

DOI:10.15835/buasvmcn-hort: 2020.0059

\begin{abstract}
Quinoa has been cultivated since centuries in the Andean region as a seed crop by indigenous communities. The crop has gained renewed interest because of its highly nutritious grain with high-quality protein rich in essential amino acids, and several bioactive compounds, along with its ability to grow under stress conditions. Despite the importance of the crop, limited research work on breeding aspects has been undertaken, leading to lack of information on the understanding of levels of variability of genotypes for different traits and their interactions. The aim of the present study was to assess and quantify the early response to mass selection in two quinoa landraces in highland conditions. Mass selection experiments were conducted during two successive crop seasons using eleven morphological traits. Correlation, genetic gain (gg) per selection cycle and principal component analysis was carried out. Only plant height (PH) and number of branches (NB) presented changes between selection cycles in both germplasm lines. Grain yield per plant (GYP) was positively correlated with inflorescence length (IL), stem diameter (SD) and plant weight (PW) for both quinoa lines. The results obtained would be useful to facilitate selection of the most relevant variables of quinoa considering its variation and interactions in the highland environment in Chile.
\end{abstract}

Keywords: mass selection, highland, saponin

\section{Introduction}

Quinoa (Chenopodium quinoa Willd.) is an ancient crop that has been cultivated for the past $7,000-8,000$ years in the mountain regions of the Andes in South America (Fuentes et al., 2009). The crop has gained worldwide attention and renewed popularity because of its highly nutritious grain with high-quality protein (particularly rich in essential amino acids) and several bioactive compounds, along with its ability to grow under stress conditions (Fuentes and Bhargava, 2011; Fuentes and Paredes-Gonzalez, 2015; Martínez et al., 2015). Quinoa grain is considered the most important component of the food chain across a broad area of the Andes, including parts of Bolivia, Peru, Ecuador, Colombia, Argentina and Chile (Vázquez-Luna et al., 2019; Angeli et al., 2020). In consideration of all these factors, the year 2013 was declared "The International Year of Quinoa" by the United Nations Food and Agriculture Organization (FAO), in recognition of its role in attaining food and nutritional security, and its potential for eradicating poverty (United Nations, 2011).

In Chile, quinoa is produced on small-scale on approximately 220 ha in the highlands of Atacama Desert, representing $31.2 \%$ of the national area 
under its cultivation (Fuentes et al., 2017). Given the enormous international demand for quinoa, indigenous communities have transformed their crop management system towards intensive production, including grain transformation for diversification of value-added products. However, the development of these initiatives is still hampered by the heterogeneous quality of its grain, primarily due to the use of a mixture of landraces for cultivation by the farmers who presume that a broader genetic base may reduce the risk of crop to variations in the environment (Fuentes et al., 2005, 2009). Due to the above mentioned production strategy, this practice is characterized by low grain yields $\left(\sim 500 \mathrm{~kg} \mathrm{ha}^{-1}\right)$ and its heterogeneity that makes it non-suitable for marketable production (Bazile et al., 2014).

Grain yield and grain size are frequently used as selection criteria for quinoa breeding programs because of their influence on commercial quality (Bhargava et al., 2006; Madrid et al., 2018; Murphy et al., 2018). The main breeding methods used in quinoa include mass selection, individual selection, pedigree method, hybridization and backcrossing (Murphy et al., 2018; Peterson et al., 2015). The intra- and inter-population selection have been quite successful in exploiting the local adaptation of selected genotypes for increasing grain production (Bertero et al., 2004).

In quinoa, different analytical approaches have been employed to analyse the germplasm variability based on different morphological traits. An investigation of genotype $\times$ environment $(G \times E)$ interaction of ten varieties of quinoa in England demonstrated that variables of grain yield, number of days to anthesis and maturity were strongly dependent on the variety that led to the conclusion that earliness and grain yield were strongly associated at the level of variety, but the pattern of $\mathrm{G} \times \mathrm{E}$ interaction differed among the variables measured (Risi and Galwey, 1991). Another study of stability for quantitative traits in fourteen quinoa lines suggested that selection for height, inflorescence size and developmental stage could be easily performed at an early stage of a breeding program (Jacobsen et al., 1996). Similarly, an investigation on developmental stability under North European conditions has suggested the selection of early, uniformly maturing plant with more branches, low saponin content and high seed yield (Jacobsen, 1998). A comprehensive multi-environment trial, involving multiple quinoa cultivars under irrigation conditions across three continents assessed the grain yield and grain size nature of the geno- types and the $\mathrm{G} \times \mathrm{E}$ interaction effects (Bertero et al., 2004). In this study, no single quinoa genotype group displayed consistently superior grain yield across all the environments, and the genotype and the $\mathrm{G} \times \mathrm{E}$ interaction effects observed for the duration of the crop cycle had major influence on the cultivar performance and on the form of $\mathrm{G} \times \mathrm{E}$ interaction observed for the total above-ground biomass and grain yield. It was concluded that a good average performance and broad adaptation of quinoa could come from the combination of medium-late maturity and high harvest index, and that simultaneous progress for grain yield and grain size can be expected from selection.

In spite of the great importance of quinoa cultivation in the highland areas in Northern Chile, limited research work on breeding aspects has been done, leading to lack of information on the understanding of levels of variability of genotypes for different traits and their interactions (Fuentes et al., 2009). In this context, the only report about Chilean quinoa germplasm evaluated under highland conditions displayed significant differences among variables describing grain yields and morphological traits of two quinoa genotypes, providing the basal germplasm material for this study (Fuentes et al., 2005). The aim of the present study was to assess and quantify the early response to mass selection in two quinoa landraces in highland conditions. The results obtained would be useful to facilitate selection of the most relevant variables of quinoa considering its variation and interactions in the highland environment in Chile.

\section{Materials and methods Experimental site and plant material}

Field experiments were conducted during crop season 2015-16 and 2016-17 on Ancovinto farm (19²3'23.44"S, 68³2'24.37"W, $3681 \mathrm{~m}$ above sea level) belonging to indigenous community of Ancovinto (Tarapacá Region), Chile. The zone is characterized by highland desert climate, with temperatures ranging between -17.6 and $24.4^{\circ} \mathrm{C}$, an average of 194 days with frost, and precipitation between 119.0 and $159.6 \mathrm{~mm}$ per year (Arenas, 2011). The soil type was classified as Aridisol with sandy loam texture and the following soil parameters at $0-40 \mathrm{~cm}$ depth: $\mathrm{pH}(1: 2.5)=8.8$; electrical

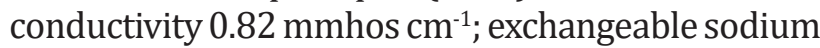
$2 \%$; and organic matter $0.7 \%$ (analysed by standard methods at Agroanalisis UC laboratories).

The plant material used comprised two quinoa lines namely, red and yellow, because of the 
inflorescence colour at grain filling stage. During the first cycle $\left(\mathrm{C}_{1}\right)$, red and yellow lines consisted in a bulked seed material of 38 and 39 quinoa genotypes respectively, which were selected according to high grain yield per plant from a mixed crop $\left(\mathrm{C}_{0}\right.$, traditional smallholder conditions), where no prior selection had taken place (Fuentes et al., 2005). For the second cycle $\left(\mathrm{C}_{2}\right)$ was used a new bulked seeds selection, which comprised 26 red and 24 yellow genotypes, selected from 100 quinoa plants according to phenotypic similarity group obtained after multivariate analysis of morphological traits (supplementary material). Both experiments were established during November and assessed morphologically at April when grain reached physiological maturity. Crop management involved soil preparation with disc plough and rotovator. Plants were thinned at threeleaf stage and weed control was managed by hand removal when required. No chemical fertilizers were used during the experiments. Irrigation was done by furrow when soil water reached $50 \%$ of field capacity at $30 \mathrm{~cm}$ depth.

The experiments were conducted in a randomized complete block design with five replications. The plot size was $50 \mathrm{~m}^{2}(5 \mathrm{~m} \times 10 \mathrm{~m})$ with a distance of $1 \mathrm{~m}$ between rows and $0.4 \mathrm{~m}$ between plants. Twenty plants were randomly selected in each replication to assess 11 morphological descriptors as follows: $\mathrm{PH}=$ plant height $(\mathrm{cm})$; IW $=$ inflorescence width $(\mathrm{cm}) ; \mathrm{IL}=$ inflorescence length $(\mathrm{cm}) ; \mathrm{SD}=$ stem diameter $(\mathrm{mm}) ; \mathrm{NB}=$ number of branches $\left(\mathrm{n}^{\circ}\right)$; $\mathrm{PW}=$ plant weight $(\mathrm{g})$; $100 \mathrm{SW}=100$ seed weight $(\mathrm{g}) ; \mathrm{GD}=$ grain diameter $(\mathrm{mm}) ; \mathrm{GYP}=$ grain yield plant $^{-1}(\mathrm{~g}) ; \mathrm{HI}=$ harvest index (\%) and SC = saponin content $\left(\mathrm{mg} \mathrm{g}^{-1}\right)$. The definition of variation among each descriptor was made according to (IBPGR, 1981). Saponin content was measured using Koziol's standardized afrosimetric test (Koziol, 1991).

\section{Data analysis}

An analysis of variance, combining quinoa lines and selection cycles was performed by the statistical software INFOSTAT ${ }^{\circledR}$ (Di Rienzo et al., 2016). Means of each trait for two lines and two cycles were used to make mean comparison with Tukey's test at $p=0.05$ and 0.01 . Genetic gain (gg) per selection cycle for each morphological descriptor was estimated using the following equation (Molina, 1992):

$$
g g=100 \mathrm{~b}_{\mathrm{y} / \mathrm{x}} / \mathrm{y}_{0}
$$

where $b_{y / x}$ is the coefficient of regression of the expression of trait $(y)$ over selection cycles $(x)$, and $y_{0}$ is the expression of the trait in cycle $\mathrm{C}_{0}$.

Multivariate analysis was carried out for each quinoaline to establish phenotypic similarity group using Pearson's coefficient for total correlation among variables (Clifford and Stephenson, 1975), principal component analysis (PCA) (Hair et al., 1998) and cluster analysis.

\section{Results and discussion}

In the general ANOVA (Tab. 1) an effect of the cycle was observed for PH, NB, GD, GYP, and

Table 1. General ANOVA of two quinoa lines in two selection cycles. Mean sum of squares (MSS) for eleven morphological traits.

\begin{tabular}{lcccccccccccc}
\hline $\begin{array}{l}\text { Source of } \\
\text { variation }\end{array}$ & df & PH & IW & IL & SD & NB & PW & 100SW & GD & GYP & HI & SC \\
\hline Model & 7 & $1584.63^{* *}$ & $1134.05^{*}$ & $143.83^{* *}$ & 9.95 & $151.93^{* *}$ & $20594.77^{*}$ & 0.0027 & $0.14^{* *}$ & $7041.23^{* *}$ & $0.05^{* *}$ & $0.86^{*}$ \\
Cycle & 1 & $1408.51^{* *}$ & 5.60 & 11.36 & 0.05 & $113.29^{* *}$ & 3151.56 & 0.0016 & $0.10^{* *}$ & $1888.79^{* *}$ & $0.01^{*}$ & 0.19 \\
Line & 1 & 64.94 & $679.31^{* *}$ & 0.26 & 1.71 & 9.80 & 3724.81 & 0,00000 & 0.0039 & 263.83 & 0.0039 & 0.27 \\
Block & 4 & 47.94 & 135.66 & 11.53 & 4.06 & 20.90 & 2764.39 & 0.001 & 0.01 & 596.74 & 0.01 & 0.12 \\
Year x Cycle & 1 & 63.23 & $313.47^{*}$ & $120.69^{* *}$ & 4.13 & 7.94 & $10954.01^{*}$ & 0.00008 & $0.02^{*}$ & $4291.86^{* *}$ & $0.02^{* *}$ & 0.27 \\
Error & 12 & 276.20 & 689.33 & 46.41 & 12.12 & 30.93 & 15860.44 & 0.01 & 0.05 & 1860.03 & 0.02 & 0.88 \\
Total & 19 & & & & & & & & & & & \\
\hline CV & & 5.23 & 11.51 & 6.12 & 6.76 & 9.51 & 21.05 & 4.48 & 2.59 & 20.20 & 10.60 & 14.73 \\
\hline
\end{tabular}

Note: * Significant at $p \leq 0.05 ;{ }^{* *}$ Significant at $p \leq 0.01 ; \mathrm{CV}=$ Coefficient of variation; PH = Plant height (cm); IW = Inflorescence width (cm); IL = Inflorescence length (cm); SD = Stem diameter (mm); NB = Number of branches $\left(\mathrm{n}^{\circ}\right)$; PW = Plant weight $(\mathrm{g}) ; 100 \mathrm{SW}=100$ seed weight $(\mathrm{g})$; $\mathrm{GD}=$ Grain diameter $(\mathrm{mm}) ; \mathrm{GYP}=$ Grain yield plant $^{-1}(\mathrm{~g}) ; \mathrm{HI}=$ Harvest index $(\%) ; \mathrm{SC}=$ Saponin content $\left(\mathrm{mg} \mathrm{g}^{-1}\right)$. 
Table 2. Mean \pm SE of eleven morphological traits of two quinoa lines in two selection cycles

\begin{tabular}{|c|c|c|c|c|c|}
\hline Trait & Cycle & Red line & Yellow line & & CV (\%) \\
\hline \multirow{4}{*}{ PH } & $\mathrm{C}_{1}$ & $86.98 \pm 2.36$ & $79.82 \pm 2.70$ & ns & 6.80 \\
\hline & $\mathrm{C}_{2}$ & $100.21 \pm 1.40$ & $100.16 \pm 1.17$ & ns & 2.89 \\
\hline & & $* *$ & $* *$ & & \\
\hline & CV (\%) & 4.64 & 5.17 & & \\
\hline \multirow{4}{*}{ IW } & $\mathrm{C}_{1}$ & $64.52 \pm 2.36$ & $68.26 \pm 1.93$ & ns & 7.25 \\
\hline & $\mathrm{C}_{2}$ & $55.54 \pm 2.95$ & $75.12 \pm 4.82$ & $*$ & 13.69 \\
\hline & & $*$ & ns & & \\
\hline & CV (\%) & 9.95 & 11.45 & & \\
\hline \multirow{4}{*}{ IL } & $\mathrm{C}_{1}$ & $35.46 \pm 1.16$ & $30.32 \pm 0.72$ & $* *$ & 6.58 \\
\hline & $\mathrm{C}_{2}$ & $29.04 \pm 0.85$ & $33.73 \pm 0.56$ & $*$ & 5.10 \\
\hline & & $* *$ & $* *$ & & \\
\hline & CV (\%) & 7.05 & 4.50 & & \\
\hline \multirow{4}{*}{ SD } & $\mathrm{C}_{1}$ & $14.98 \pm 0.81$ & $14.65 \pm 0.23$ & ns & 8.94 \\
\hline & $\mathrm{C}_{2}$ & $14.16 \pm 0.22$ & $15.66 \pm 0.24$ & $*$ & 3.49 \\
\hline & & ns & $*$ & & \\
\hline & CV (\%) & 9.06 & 3.50 & & \\
\hline \multirow{4}{*}{ NB } & $\mathrm{C}_{1}$ & $14.44 \pm 0.78$ & $14.58 \pm 0.34$ & ns & 9.32 \\
\hline & $\mathrm{C}_{2}$ & $17.94 \pm 1.29$ & $20.60 \pm 0.46$ & ns & 11.19 \\
\hline & & $*$ & $* *$ & & \\
\hline & CV (\%) & 14.70 & 5.14 & & \\
\hline \multirow{4}{*}{ PW } & $\mathrm{C}_{1}$ & $169.90 \pm 25.68$ & $150.39 \pm 8.22$ & ns & 26.62 \\
\hline & $\mathrm{C}_{2}$ & $148.20 \pm 8.25$ & $222.30 \pm 11.67$ & $* *$ & 12.20 \\
\hline & & ns & $* *$ & & \\
\hline & CV (\%) & 26.81 & 12.11 & & \\
\hline \multirow{4}{*}{ 100SW } & $\mathrm{C}_{1}$ & $0.51 \pm 0.01$ & $0.51 \pm 0.01$ & ns & 5.08 \\
\hline & $\mathrm{C}_{2}$ & $0.49 \pm 0.004$ & $0.49 \pm 0.01$ & ns & 2.98 \\
\hline & & ns & ns & & \\
\hline & CV (\%) & 3.60 & 4.72 & & \\
\hline \multirow{4}{*}{ GD } & $\mathrm{C}_{1}$ & $2.54 \pm 0.02$ & $2.45 \pm 0.04$ & ns & 2.66 \\
\hline & $\mathrm{C}_{2}$ & $2.33 \pm 0.01$ & $2.37 \pm 0.03$ & ns & 2.00 \\
\hline & & $* *$ & ns & & \\
\hline & CV (\%) & 1.34 & 3.09 & & \\
\hline \multirow{4}{*}{ GYP } & $\mathrm{C}_{1}$ & $62.92 \pm 6.87$ & $40.89 \pm 6.52$ & $*$ & 28.87 \\
\hline & $\mathrm{C}_{2}$ & $53.06 \pm 2.12$ & $89.62 \pm 5.34$ & $* *$ & 12.74 \\
\hline & & ns & $* *$ & & \\
\hline & CV (\%) & 19.61 & 20.43 & & \\
\hline \multirow{4}{*}{ HI } & $\mathrm{C}_{1}$ & $0.38 \pm 0.02$ & $0.29 \pm 0.03$ & $*$ & 17.67 \\
\hline & $\mathrm{C}_{2}$ & $0.37 \pm 0.01$ & $0.41 \pm 0.01$ & $* *$ & 4.20 \\
\hline & & ns & $* *$ & & \\
\hline & CV (\%) & 8.54 & 15.04 & & \\
\hline \multirow{4}{*}{ SC } & $\mathrm{C}_{1}$ & $2.17 \pm 0.17$ & $1.71 \pm 0.12$ & ns & 17.16 \\
\hline & $\mathrm{C}_{2}$ & $1.74 \pm 0.07$ & $1.74 \pm 0.04$ & ns & 7.06 \\
\hline & & $*$ & ns & & \\
\hline & CV (\%) & 15.01 & 11.53 & & \\
\hline
\end{tabular}

Note: * Significant at $p \leq 0.05 ;{ }^{* *}$ Significant at $p \leq 0.01 ; \mathrm{ns}=$ Non-significant; $\mathrm{CV}=$ Coefficient of variation;

$\mathrm{PH}=$ Plant height $(\mathrm{cm}) ; \mathrm{IW}=$ Inflorescence width $(\mathrm{cm}) ; \mathrm{IL}=$ Inflorescence length $(\mathrm{cm}) ; \mathrm{SD}=$ Stem diameter $(\mathrm{mm}) ; \mathrm{NB}=$ Number of branches $\left(\mathrm{n}^{\circ}\right) ; \mathrm{PW}=$ Plant weight $(\mathrm{g}) ; 100 \mathrm{SW}=100$ seed weight $(\mathrm{g}) ; \mathrm{GD}=$ Grain diameter (mm); GYP = Grain yield plant ${ }^{-1}(\mathrm{~g}) ; \mathrm{HI}=$ Harvest index (\%); SC $=$ Saponin content $\left(\mathrm{mg} \mathrm{g}^{-1}\right)$. 
HI variables ( $p \leq 0.01$ and 0.05$)$. The IW variable was significantly influenced by the line effect $(p \leq 0.01)$, while the other traits did not show significant differences. For IW, IL, PW, GD, GYP and $\mathrm{HI}$ variables, an interaction of cycle with line was observed ( $p \leq 0.01$ and 0.05 ). These findings and the high coefficient of variation values observed in GYP $(20.20 \%)$ and PW (21.05\%) indicate the existence of a high degree of variability for these two morphological descriptors influenced by the cycle and the interaction cycle $\times$ line, respectively. The selection of the best progenies for next cycles should therefore be based on the average of analysis of variance of cycles.

The variance analysis of eleven morphological descriptors in both quinoa lines and selections cycles are shown in Table 2. Among the variables assessed in this study, only PH and NB presented increased values $(p \leq 0.05)$ between selection cycles in both quinoa lines. The variable of $100 \mathrm{SW}$ did not show differences $(p \leq 0.05)$ between cycles for both quinoa lines, being in addition the only variable that did not register significant changes during the selection process. This shows that mass selection can be safely practiced in quinoa and this would not lead to decrease in grain weight. The remaining variables in this study showed differences $(p \leq 0.05)$ indistinctly between cycles in one or both lines, standing out in the red line the decreasing of GD and SC variables, and in the yellow line the increasing of PW, GYP and HI. The comparison between lines in both selection cycles showed significant differences $(p \leq 0.05)$ only for IL, GYP and HI variables, which were not consistent with a distinctive morphological pattern between lines.

Genetic gain, a product of heritability and selection differential, has been frequently used as a guiding factor in selection programmes in a number of plants (Badigannavar and Ganapathi, 2018; Kumar and Das, 2018; Mishra et al., 2015) including quinoa (Bhargava et al., 2007, 2008; Madrid et al., 2018). After two selection cycles, the results demonstrated that the red line presented a positive genetic gain $(p \leq 0.05)$ for the $\mathrm{PH}$ and NB variables and a negative genetic gain for IW, IL, GD and SC (Tab. 3). Similarly, in the yellow line the genetic gain was positive for the PH, IL, NB, PW, GYP and HI variables; and negative only for GD. Furthermore, it was observed that the coefficients of variation for most of variables in $\mathrm{C}_{2}$ decreased in comparison with $\mathrm{C}_{1}$ for both quinoalines, excepting for IW and NB variables in the red line and only in IW in the yellow one, which showed an increase of

Table 3. Genetic gain (gg) and coefficient of variation (CV) for eleven morphological traits of two selection cycles in two quinoa lines.

\begin{tabular}{|c|c|c|c|c|c|c|c|c|c|c|}
\hline \multirow{2}{*}{ Descriptor } & \multicolumn{5}{|c|}{ Red line } & \multicolumn{5}{|c|}{ Yellow line } \\
\hline & $\boldsymbol{b}_{y / x}$ & $\mathbf{r}^{2}$ & gg (\%) & $\mathrm{CV} \mathrm{C}_{1}$ & $\mathrm{CV} \mathrm{C}_{2}$ & $\boldsymbol{b}_{y / x}$ & $\mathbf{r}^{2}$ & gg (\%) & $\mathrm{CV} \mathrm{C}_{1}$ & $\mathrm{CV} \mathrm{C}_{2}$ \\
\hline Plant height $(\mathrm{cm})$ & $13.3^{* *}$ & 0.3 & $15.29 * *$ & 6.07 & 3.13 & $20.46^{* *}$ & 0.4 & $25.63^{* *}$ & 7.57 & 2.62 \\
\hline Inflorescence width (cm) & $-9.23^{* *}$ & 0.11 & $-14.31^{* *}$ & 8.17 & 11.89 & $7.14 \mathrm{~ns}$ & 0.03 & $10.46 \mathrm{~ns}$ & 6.31 & 14.36 \\
\hline Inflorescence length $(\mathrm{cm})$ & $-6.4^{* *}$ & 0.27 & $-18.05^{* *}$ & 7.33 & 6.51 & $3.57^{*}$ & 0.07 & $11.77^{* *}$ & 5.33 & 3.68 \\
\hline Stem diameter $(\mathrm{mm})$ & $-0.76 \mathrm{~ns}$ & 0.02 & -5.07 ns & 12.02 & 3.48 & $1.04 \mathrm{~ns}$ & 0.03 & $7.10 \mathrm{~ns}$ & 3.51 & 3.49 \\
\hline Number of branches $\left(n^{\circ}\right)$ & $3.38^{* *}$ & 0.12 & $23.41^{* *}$ & 12.12 & 16.02 & $6.13^{* *}$ & 0.33 & $42.04^{* *}$ & 5.28 & 4.96 \\
\hline Plant weight (g) & -21.23 ns & 0.02 & $-12.50 \mathrm{~ns}$ & 33.79 & 12.45 & $73.83^{* *}$ & 0.19 & $49.09 * *$ & 12.23 & 11.74 \\
\hline 100 seed weight (g) & -0.02 ns & 0.03 & $-3.92 \mathrm{~ns}$ & 4.70 & 1.81 & $-0.02 \mathrm{~ns}$ & 0.03 & $-3.92 \mathrm{~ns}$ & 5.42 & 3.82 \\
\hline Grain diameter (mm) & $-0.21^{* *}$ & 0.33 & $-8.27^{* *}$ & 1.38 & 1.30 & $-0.07^{*}$ & 0.05 & $-2.86^{*}$ & 3.55 & 2.50 \\
\hline Grain yield plant $^{-1}(\mathrm{~g})$ & $-9.79 \mathrm{~ns}$ & 0.03 & $-15.56 \mathrm{~ns}$ & 24.43 & 8.94 & $49 * *$ & 0.39 & $119.83^{* *}$ & 35.67 & 13.33 \\
\hline Harvest index (\%) & $-0.01 \mathrm{~ns}$ & 0.0043 & $-2.63 n s$ & 10.85 & 5.06 & $0.12^{* *}$ & 0.21 & $41.38^{* *}$ & 25.21 & 3.30 \\
\hline Saponin content $\left(\mathrm{mg} \mathrm{g}^{-1}\right)$ & $-0.43^{* *}$ & 0.1 & $-19.82^{* *}$ & 17.89 & 8.45 & $0.03 \mathrm{~ns}$ & 0.00042 & $1.75 \mathrm{~ns}$ & 15.55 & 5.33 \\
\hline
\end{tabular}

Note: $b_{y / x}=$ coefficient of regression; $\mathrm{r}^{2}=$ coefficient of determination; gg (\%) = genetic gain (Molina, 1992); ${ }^{*} p \leq$ $0.05 ; * * x \leq 0.01 ; \mathrm{ns}=$ non-significant 
their values. The moderate to high positive genetic gain observed for the abovementioned traits indicate that improvement could be made in the aforesaid characters.

Correlation coefficients show relationships among various traits along with the degree of linear relation between these characters (Bhargava et al., 2008). The correlation analysis in both cycles (Tab. 4) exhibited 14 (25.5\%) significant associations $(p \leq 0.05)$ in the red line, of which three were negative $(\mathrm{PH} / \mathrm{GD}, \mathrm{R}=-0.77$; NB/100SW, $\mathrm{R}=-0.65$ and NB/GD, $R=-0.68$ ). Contrary to the observed in the red line, the yellow line did not show any significant negative correlations. The yellow line had $21(38.2 \%)$ significant correlations ( $p \leq$ 0.05 ) all of them being positive. Grain yield per plant (GYP) had a large number of significant associations, positively correlating with IL, SD and PW for both the germplasm lines. High significant positive correlation values between inflorescence length and seed yield have also been observed in plants like barnyard grass (Norris, 1992), sorghum (Kenga et al., 2006) and perennial ryegrass (Abel et al., 2017). Likewise, significant positive association between seed yield and stem diameter as obtained in the present study has also been observed in other economically important plants like maize (Ali et al., 2017), wheat (Okuyama et al., 2005) and quinoa (Bhargava et al., 2008; Madrid et al., 2018). Thus, IL, SD and PW should be given proper attention in selection programmes for increasing grain yield in quinoa. Another interesting feature of the study was the non-significant association of $\mathrm{HI}$ and SC for the red line (Tab. 4).

The principal component analysis (PCA) of the red line accounted $43.8 \%$ and $31.4 \%$ of the variability accounted for by PC1 and PC2, respectively (75.2\% of total variation) (Fig. 1A). Morphological descriptors that contributed most to variability in PC1 were IL and IW (collectively termed the inflorescence components); GYP, SD and PW (collectively termed the above-ground biomass components); and SC and GD (collectively termed the grain quality components); while in PC2, PH and NB (collectively termed the plant architecture components) were the largest contributors to variability. In the yellow line PC1 and PC2 accounted for $57.0 \%$ and $19.4 \%$ of the variability $(76.4 \%$ of total variation) (Fig. 1B). Traits that contributed most to variability in PC1 were GYP, PW, NB, PH and HI (collectively termed the above-ground biomass components); and IL, SD and IW (collectively termed the inflorescence components); while in PC2, GD, 100SW and SC (collectively termed the grain quality components) were the largest contributors to the component.

Table 4. Pearson coefficient of correlation among morphological variables of quinoa accessions (yellow line $\backslash$ red line)*

\begin{tabular}{cccccccccccc}
\hline & PH & IW & IL & SD & NB & PW & $\mathbf{1 0 0 S W}$ & GD & GYP & HI & SC \\
\hline PH & 1 & -0.36 & -0.51 & 0.05 & 0.62 & 0.16 & -0.55 & $-\mathbf{0 . 7 7}$ & -0.02 & -0.39 & -0.5 \\
\hline IW & 0.39 & 1 & $\mathbf{0 . 8 4}$ & $\mathbf{0 . 6 7}$ & -0.15 & $\mathbf{0 . 6 6}$ & 0.06 & 0.61 & $\mathbf{0 . 7 6}$ & -0.1 & 0.37 \\
\hline IL & $\mathbf{0 . 9}$ & 0.59 & 1 & $\mathbf{0 . 6 5}$ & -0.32 & $\mathbf{0 . 6 5}$ & 0.01 & $\mathbf{0 . 8 2}$ & $\mathbf{0 . 7 8}$ & -0.0023 & 0.55 \\
\hline SD & $\mathbf{0 . 7 2}$ & 0.59 & $\mathbf{0 . 7 2}$ & 1 & 0.21 & $\mathbf{0 . 8 7}$ & -0.41 & 0.3 & $\mathbf{0 . 9}$ & -0.38 & 0.21 \\
\hline NB & $\mathbf{0 . 8 5}$ & 0.51 & $\mathbf{0 . 7 4}$ & $\mathbf{0 . 6 5}$ & 1 & 0.22 & $\mathbf{- 0 . 6 5}$ & $\mathbf{- 0 . 6 8}$ & 0.16 & -0.2 & -0.28 \\
\hline PW & $\mathbf{0 . 7 7}$ & 0.59 & $\mathbf{0 . 7 5}$ & $\mathbf{0 . 8 3}$ & $\mathbf{0 . 8 5}$ & 1 & -0.37 & 0.31 & $\mathbf{0 . 9 5}$ & -0.56 & 0.06 \\
\hline 100SW & -0.19 & 0.16 & 0.16 & -0.14 & -0.47 & -0.33 & 1 & 0.47 & -0.41 & -0.11 & 0.15 \\
\hline GD & -0.34 & 0.36 & -0.08 & 0.05 & -0.44 & -0.37 & $\mathbf{0 . 6 9}$ & 1 & 0.42 & 0.01 & 0.56 \\
\hline GYP & $\mathbf{0 . 8 4}$ & 0.51 & $\mathbf{0 . 8 1}$ & $\mathbf{0 . 7 6}$ & $\mathbf{0 . 8 6}$ & $\mathbf{0 . 9 7}$ & -0.27 & -0.45 & 1 & -0.3 & 0.29 \\
\hline HI & $\mathbf{0 . 7 8}$ & 0.36 & $\mathbf{0 . 7 1}$ & 0.56 & $\mathbf{0 . 7 9}$ & $\mathbf{0 . 8 2}$ & -0.18 & -0.48 & $\mathbf{0 . 9 2}$ & 1 & 0.48 \\
\hline SC & 0.08 & 0.24 & -0.01 & 0.22 & 0.1 & -0.13 & -0.24 & 0.37 & -0.23 & -0.44 & 1 \\
\hline
\end{tabular}

Note: *Values in bold represent significant correlations $(p \leq 0.05) ; \mathrm{PH}=$ Plant height $(\mathrm{cm})$; IW = Inflorescence width $(\mathrm{cm}) ; \mathrm{IL}=$ Inflorescence length $(\mathrm{cm}) ; \mathrm{SD}=$ Stem diameter $(\mathrm{mm}) ; \mathrm{NB}=$ Number of branches $\left(\mathrm{n}^{\circ}\right) ; \mathrm{PW}=$ Plant weight $(\mathrm{g}) ; 100 \mathrm{SW}=100$ seed weight $(\mathrm{g}) ; \mathrm{GD}=\mathrm{Grain}$ diameter $(\mathrm{mm}) ; \mathrm{GYP}=$ Grain yield plant ${ }^{-1}(\mathrm{~g}) ; \mathrm{HI}=$ Harvest index $(\%) ; \mathrm{SC}=$ Saponin content $\left(\mathrm{mg} \mathrm{g}^{-1}\right)$. 
These findings revealed that both quinoa lines were mainly influenced by above-ground biomass and inflorescence component and secondary by grain quality components.

Saponin content in quinoa grain has been described under qualitative and quantitative genetic control, representing a main breeding goal in the development of saponin-free varieties
(Mastebroek et al., 2000; Murphy et al., 2018). Even though the efforts to breed low-saponin varieties quantitatively have not been successful, due to a lack of sufficient response to selection (Ward, 2001), considerable genetic variation for saponin content on-farm is still available for selection purposes (Bhargava and Ohri, 2016; El Hazzam et al., 2020). In our study, the frequency

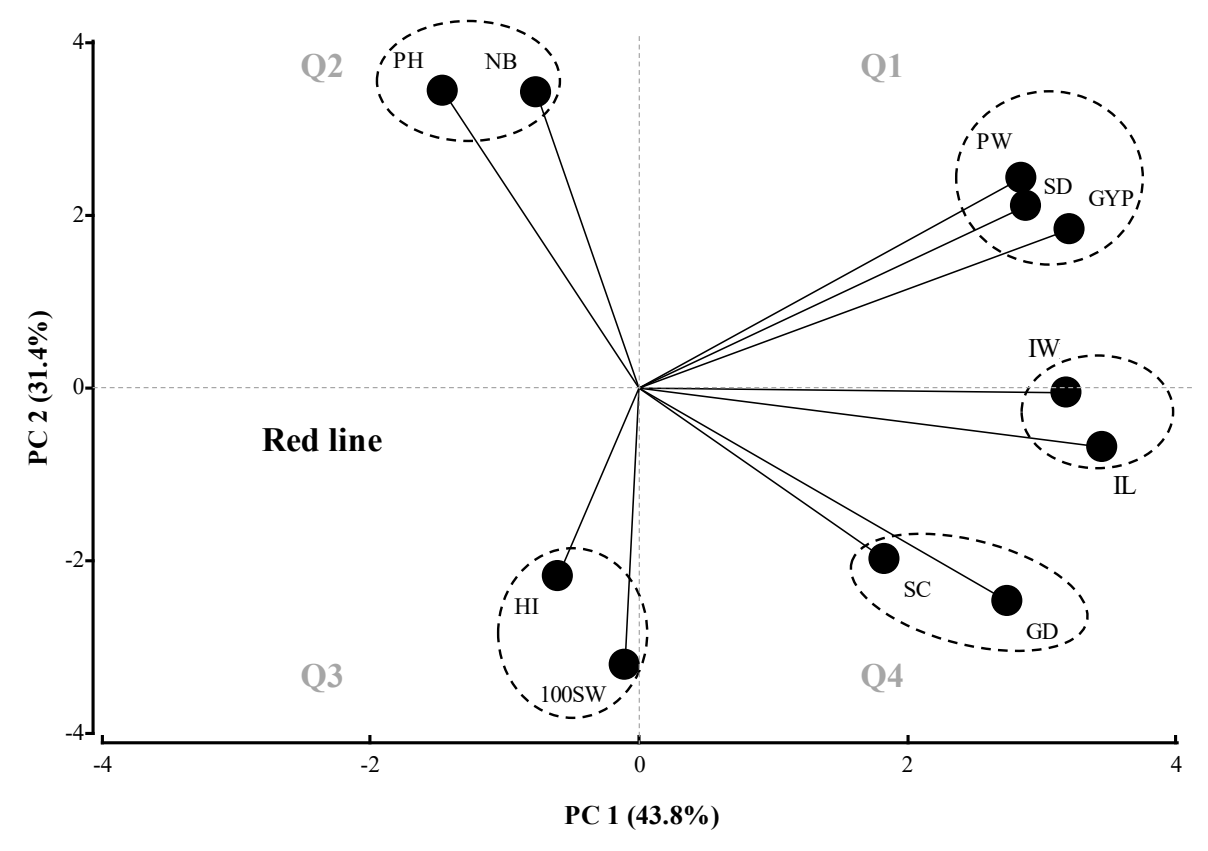

A.

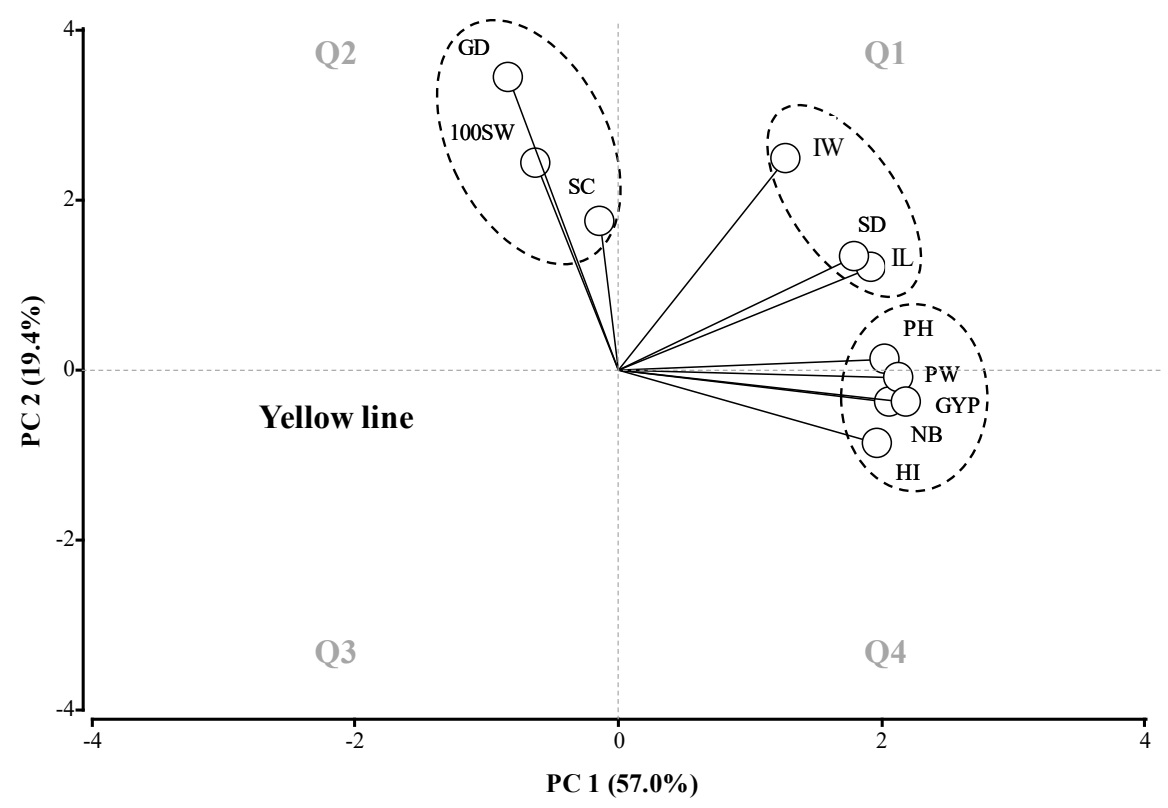

B.

Figure 1. Principal component analysis

for red (A) and yellow (B) quinoa lines under highlands conditions in northern Chile

$\mathrm{PH}=$ Plant height $(\mathrm{cm}) ; \mathrm{IW}=$ Inflorescence width $(\mathrm{cm}) ; \mathrm{IL}=$ Inflorescence length $(\mathrm{cm}) ; \mathrm{SD}=$ Stem diameter $(\mathrm{mm}) ; \mathrm{NB}=\mathrm{Number}$ of branches $\left(\mathrm{n}^{\circ}\right)$; PW = Plant weight (g); 100SW = 100 seed weight $(\mathrm{g})$; GD = Grain diameter (mm); GYP = Grain yield plant ${ }^{-1}(\mathrm{~g})$; HI = Harvest index $(\%) ;$ SC $=$ Saponin content $\left(\mathrm{mg} \mathrm{g}^{-1}\right)$. 
distribution of saponin content for both genetic lines in the first cycle showed a wide dispersion (being the red line more bitter than the yellow), exhibiting several sweet genotypes with a low saponin content (Fig. 2). These observations reveal that further improvements could be made in new selection cycles.
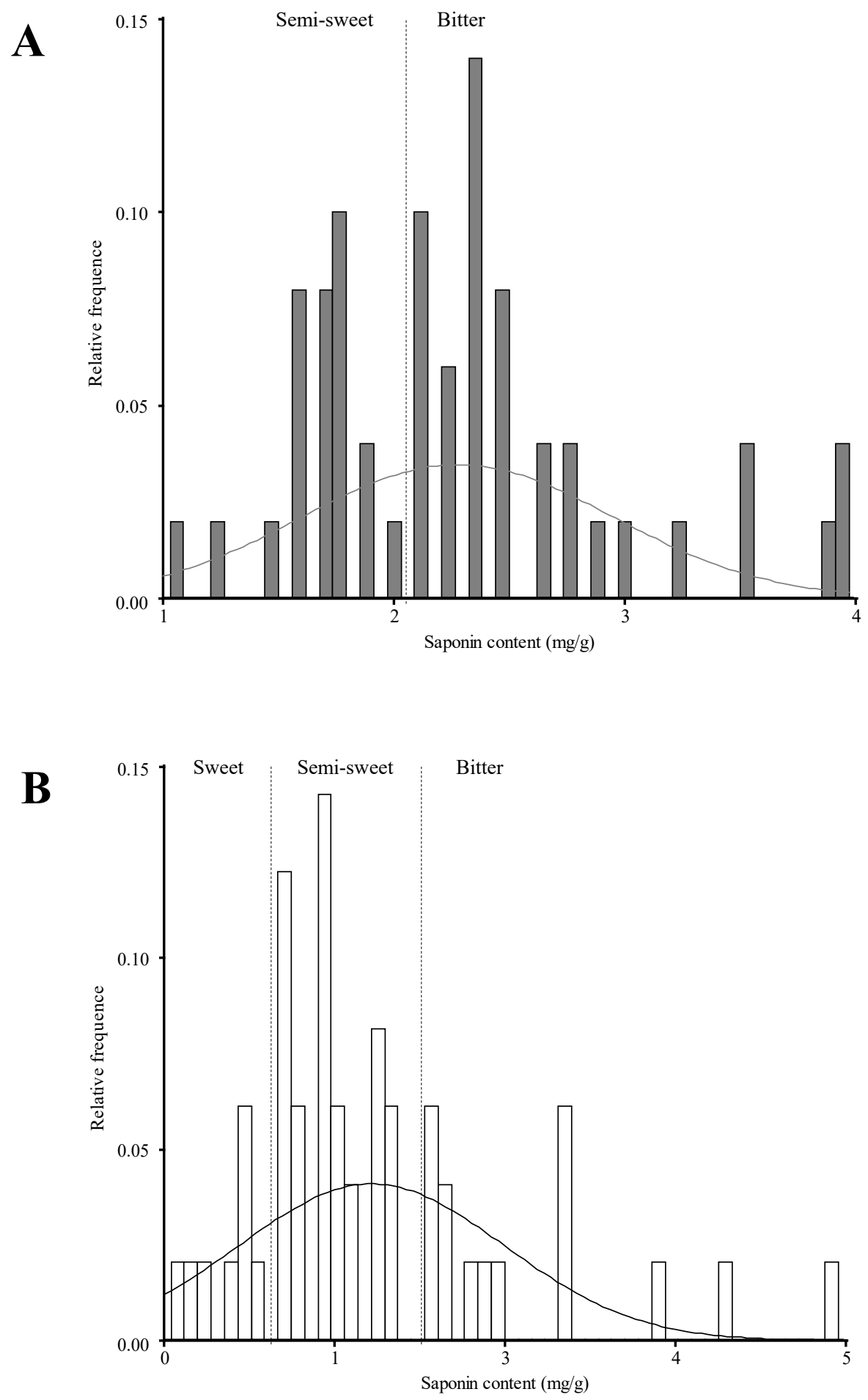

Figure 2. Frequency distribution of saponin content for red (A) and yellow (B) quinoa lines in $C_{1}$ 


\section{Conclusions}

The results indicate that a substantial part of the observed phenotypic variance for grain yield is additive genetic variance. Therefore, mass selection for grain yield in quinoa is likely to be effective. More effective improvement would be observed in grain quality component such as saponin content if selection on the improved populations is carried out beyond the two cycles.

\section{Acknowledgments}

We thank all the QuinoaLab UC members for their helpful discussion and preparation of this manuscript. This work was supported by institutional funds and by PYT-2016-0450 from FIA.

\section{References}

1. Abel S, Gislum R, Boelt B (2017). Path and correlation analysis of perennial ryegrass (Lolium perenne L.) seed yield components. Journal of Agronomy and Crop Science, 203(4): 338-344.

2. Ali F, Ahsan M, Ali Q, Kanwal N (2017). Phenotypic stability of Zea mays grain yield and its attributing traits under drought stress. Frontiers in Plant Science, 8: 1-11.

3. Angeli V, Silva PM, Massuela DC, Khan MW, Hamar A, Khajehei F, Graeff-Hönninger S, Piatti C (2020). Quinoa (Chenopodium quinoa Willd.): An overview of the potentials of the "golden grain" and socio-economic and environmental aspects of its cultivation and marketization. Foods, 9(2): 216.

4. Arenas J (2011). Observatorio del clima para el año 2010 en el sector Vilacollo, comuna de Colchane, provincia del Tamarugal, región de Tarapacá, Universidad Arturo Prat ed.

5. Badigannavar A, Ganapathi TR (2018). Genetic variability for mineral nutrients in indigenous germplasm lines of finger millet (Eleusine coracana Gaertn.). Journal of Cereal Science. https://doi.org/10.1016/j.jcs.2018.09.014

6. Bazile D, Martínez EA, Fuentes F (2014). Diversity of quinoa in a biogeographical Island: A review of constraints and potential from arid to temperate regions of Chile. Notulae Botanicae Horti Agrobotanici Cluj-Napoca. https://doi. org/10.1583/nbha4229733

7. Bertero HD, De La Vega AJ, Correa G, Jacobsen SE, Mujica A (2004). Genotype and genotype-by-environment interaction effects for grain yield and grain size of quinoa (Chenopodium quinoa Willd.) as revealed by pattern analysis of international multi-environment trials. Field Crops Research, 89(2-3): 299-318.

8. Bhargava A, Ohri D (2016). Origin of Genetic Variability and Improvement of Quinoa (Chenopodium quinoa Willd.). In VR Rajpal, SR Rao, SN Raina eds., Gene Pool Diversity and Crop Improvement, Springer International Publishing, pp. 241-270.
9. Bhargava A, Shukla S, Ohri D (2006). Chenopodium quinoa - An Indian perspective. Industrial Crops and Products. https://doi.org/10.1016/j.indcrop.2005.04.002

10. Bhargava A, Shukla S, Ohri D (2007). Genetic variability and interrelationship among various morphological and quality traits in quinoa (Chenopodium quinoa Willd.). Field Crops Research, 101(1): 104-116.

11. Bhargava A, Shukla S, Ohri D (2008). Implications of direct and indirect selection parameters for improvement of grain yield and quality components in Chenopodium quinoa Willd. International Journal of Plant Production, 2(3): 183-191.

12. Clifford HT, Stephenson W (1975). An Introduction to Numerical Classification. Academic Press, New York.

13. Di Rienzo JA, Casanoves F, Balzarini MG, Gonzalez L, Tablada M, Robledo CW (2016). InfoStat versión 2016 (G. InfoStat ed.). FCA, Universidad Nacional de Córdoba.

14. El Hazzam K, Hafsa J, Sobeh M, Mhada M, Taourirte M, Kacimi KEL, Yasri A (2020). An insight into saponins from Quinoa (Chenopodium quinoa Willd): A review. In Molecules. https://doi.org/10.3390/molecules25051059.

15. Fuentes F, Bhargava A (2011). Morphological Analysis of Quinoa Germplasm Grown Under Lowland Desert Conditions. Journal of Agronomy and Crop Science, 197(2): 124-134.

16. Fuentes F, Delatorre J, Tello V, Arenas J, Riquelme A, Oliva M, Lanino M, Carevic A (2005). Diversidad genética intrapredial en germoplasma nativo de quinua (Chenopodium quinoa Willd.) de la Comunidad de Ancovinto, Altiplano de la I Región de Chile. Anales V SIRGEALC, Uruguay, 121.

17. Fuentes F, Martinez EA, Hinrichsen PV, Jellen EN, Maughan PJ (2009). Assessment of genetic diversity patterns in Chilean quinoa (Chenopodium quinoa Willd.) germplasm using multiplex fluorescent microsatellite markers. Conservation Genetics, 10(2): 369-377.

18. Fuentes F, Olguín P, Duarte L, Ojeda M, Figueroa C, Paredes-Gonzalez X, Martínez EA (2017). Potencial competitivo de la Quinua chilena, C Pérez ed., Fundación para la Innovación Agraria, Santiago, Chile.

19. Fuentes F, Paredes-Gonzalez X (2015). Nutraceutical Perspectives of Quinoa: Biological Properties and Functional Applications. In D Bazile, D Bertero, C Nieto eds., The state of the world's quinoa FAO - CIRAD, pp. 286-299.

20. Hair JF, Anderson RE, Tatham RL, Black WC (1998). Multivariate data analysis with readings (5nd ed.). Upper Saddle River, N.J.: Prentice Hall.

21. IBPGR (1981). Descriptores de quinua. Internacional Board for plant genetic Resources, Roma, Italia.

22. Jacobsen SE, Hill J, Stølen O (1996). Stability of quantitative traits in quinoa (Chenopodium quinoa). Theoretical and Applied Genetics, 93(1-2): 110-116.

23. Jacobsen SE (1998). Developmental stability of quinoa under European conditions. Industrial Crops and Products, 7(2-3): 169-174.

24. Kenga R, Tenkouano A, Gupta SC, Alabi So (2006). Genetic and phenotypic association between yield components 
in hybrid sorghum (Sorghum bicolor L., Moench) populations. Euphytica, 150(3): 319-326.

25. Koziol MJ (1991). Afrosimetric estimation of threshold saponin concentration for bitterness in quinoa (Chenopodium quinoa Willd). Journal of the Science of Food and Agriculture, 54(2): 211-219.

26. Kumar R, Das N (2018). Survey and selection of Jatropha curcas L. germplasm: Assessment of genetic variability and divergence studies on the seed traits and oil content. Industrial Crops and Products, 118: 125-130.

27. Madrid D, Salgado E, Verdugo G, Olguín P, Bilalis D, Fuentes F (2018). Morphological traits defining breeding criteria for coastal quinoa in Chile. Notulae Botanicae Horti Agrobotanici Cluj-Napoca, 46(1): 190-196.

28. Martínez EA, Fuentes F, Bazile D (2015). History of Quinoa: Its Origin, Domestication, Diversification, and Cultivation with Particular Reference to the Chilean Context. In Quinoa: Improvement and Sustainable Production, pp. 19-24.

29. Mastebroek HD, Limburg H, Gilles T, Marvin HJP (2000). Occurrence of sapogenins in leaves and seeds of quinoa (Chenopodium quinoa Willd). Journal of the Science of Food and Agriculture, 80(1): 152-156.

30. Mishra R, Gupta AK, Lal RK, Jhang T, Banerjee N (2015). Genetic variability, analysis of genetic parameters, character associations and contribution for agronomical traits in turmeric (Curcuma longa L.). Industrial Crops and Products, 76: 204-208.

31. Molina J (1992). Introducción a la Genética de Poblaciones y Cuantitativa. (Algunas Implicaciones en Genotecnia), A. G. T. ed., México.
32. Murphy KM, Matanguihan JB, Fuentes F, Gómez-Pando LR, Jellen EN, Maughan PJ, Jarvis DE (2018). Quinoa Breeding and Genomics. Plant Breeding Reviews 42: 257-320.

33. Norris RF (1992). Relationship Between Inflorescence Size and Seed Production in Barnyardgrass (Echinochloa crus-galli), Weed Science, 40(1): 74-78.

34. Okuyama LA, Federizzi LC, Barbosa Neto JF (2005). Plant traits to complement selection based on yield components in wheat. Ciência Rural, 35(5): 1010-1018.

35. Peterson A, Jacobsen SE, Bonifacio A, Murphy K (2015). A crossing method for Quinoa. Sustainability (Switzerland). https://doi.org/10.3390/su7033230

36. Risi J, Galwey NW (1991). Genotype $\times$ Environment Interaction in the Andean Grain Crop Quinoa (Chenopodium quinoa) in Temperate Environments. Plant Breeding, 107(2): 141-147.

37. United Nations (2011). Draft resolution II, International Year of Quinoa, 2013. Agriculture Development and Food Security, Report of the Second Committee. A/ RES/66/446. http://www.un.org/ga/search/view_doc. asp?symbol=A/66/446

38. Vázquez-Luna A, Fuentes F, Rivadeneyra E, Hernández C, Díaz-Sobac R (2019). Nutrimental content and functional properties of Quinoa flour from Chile and Mexico. Ciencia e Investigacion Agraria, 46(2): 144-153.

39. Ward SM (2001). A Recessive Allele Inhibiting Saponin Synthesis in Two Lines of Bolivian Quinoa (Chenopodium quinoa Willd.). Journal of Heredity, 92(1): 83-86. 